Erratum

\title{
Erratum: An ECCD-Electronic Charge \\ Compensation Device-As a Quantum Dissipative System. Applied Sciences 2019, 9, 4879
}

\author{
Applied Sciences Editorial Office
}

MDPI AG, St. Alban-Anlage 66, 4052 Basel, Switzerland

Received: 27 November 2019; Accepted: 16 December 2019; Published: 17 December 2019

We wish to make the following correction to the published paper [1] as affiliations 2 and 3 are incorrect. They should be as follows:

2 Dinnteco International, C/Pere d'Urgel, 10, AD500 Andorra la Vella, Principado de Andorra; DINNTECO Factory Gasteiz, SL. C/Aibarra, 30. pabellón, 1. 01010 Vitoria, Spain; jmaldonado@dinnteco.com

3 ICAI, Escuela Técnica Superior de Ingeniería \& IIT, Universidad Pontificia Comillas de Madrid, C/Alberto Aguilera, 25, 28015 Madrid, Spain; msaenz@comillas.edu

The error was introduced during production and is not the fault of the authors. We apologize for any inconvenience caused to the readers and authors by this change. The change does not affect the scientific results. The manuscript will be updated and the original will remain online on the article webpage.

\section{Reference}

1. Bernabeu, E.; Maldonado, J.; Sáenz-Nuño, M.A. An ECCD—Electronic Charge Compensation Device—As a Quantum Dissipative System. Appl. Sci. 2019, 9, 4879. [CrossRef]

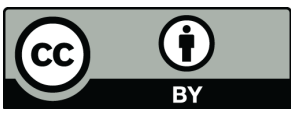

(C) 2019 by the author. Licensee MDPI, Basel, Switzerland. This article is an open access article distributed under the terms and conditions of the Creative Commons Attribution (CC BY) license (http://creativecommons.org/licenses/by/4.0/). 